Cahiers $d u$ MONDE RUSSE

\section{Cahiers du monde russe}

Russie - Empire russe - Union soviétique et États indépendants

48/2-3 | 2007

Les résonances de 1905

\title{
Greek Perceptions of the Russian Revolution of 1905
}

"Russia overcoming Russia"

\section{ADA DIALLA}

\section{CpenEdition}

\section{Journals}

Édition électronique

URL : https://journals.openedition.org/monderusse/9019

DOI : 10.4000/monderusse. 9019

ISSN : $1777-5388$

Éditeur

Éditions de l'EHESS

Édition imprimée

Date de publication : 15 avril 2007

Pagination : 463-476

ISBN : 978-2-7132-2147-7

ISSN : $1252-6576$

Référence électronique

ADA DIALLA, "Greek Perceptions of the Russian Revolution of 1905 », Cahiers du monde russe [En ligne], 48/2-3 | 2007, mis en ligne le 01 janvier 2007, consulté le 04 septembre 2022. URL : http:// journals.openedition.org/monderusse/9019; DOI : https://doi.org/10.4000/monderusse.9019 
chercher : repérer : avancer

Cet article est disponible en ligne à l'adresse :

http://www.cairn.info/article.php?ID REVUE=CMR\&ID NUMPUBLIE=CMR 482\&ID ARTICLE=CMR 4820463

\title{
Greek Perceptions of the Russian Revolution of 1905. "Russia overcoming Russia"
}

par ADA DIALLA

\section{Editions de l'EHESS | Cahiers du monde russe}

\author{
$2007 / 2-3-$ Vol 48 \\ ISSN 1252-6576 | ISBN 9782713221477 | pages 463 à 476
}

Pour citer cet article :

_DIALLA A., Greek Perceptions of the Russian Revolution of 1905. "Russia overcoming Russia", Cahiers du monde russe $2007 / 2-3$, Vol 48, p. 463-476.

Distribution électronique Cairn pour les Editions de l'EHESS.

(C) Editions de l'EHESS. Tous droits réservés pour tous pays.

La reproduction ou représentation de cet article, notamment par photocopie, n'est autorisée que dans les limites des conditions générales d'utilisation du site ou, le cas échéant, des conditions générales de la licence souscrite par votre établissement. Toute autre reproduction ou représentation, en tout ou partie, sous quelque forme et de quelque manière que ce soit, est interdite sauf accord préalable et écrit de l'éditeur, en dehors des cas prévus par la législation en vigueur en France. Il est précisé que son stockage dans une base de données est également interdit. 


\section{ADA DIALLA \\ GREEK PERCEPTIONS OF THE RUSSIAN REVOLUTION OF 1905

\author{
"Russia overcoming Russia"
}

The Greek perceptions of the 1905 Russian Revolution as it unfolded have so far not been a focus of study, not even by Greek historians. This is somewhat surprising for at the time, "1905" was viewed in Greece, as elsewhere in Europe and beyond, as a shattering world event so consequential as to be compared with the French Revolution. Even a cursory glance at the Athenian press of that year readily shows that the 1905 nationwide upheaval in Russia-the legitimacy crisis of tsarism and the Empire triggered by the 1905 defeat in the Russo-Japanese war of 1905 that led to mass rallies and clashes, which engulfed all aspects of the social and political life of the country - captured the interest and imagination of Greek public opinion as few other international events had done.

The aim of the present article is first of all to register the reactions of the Greek public, in themselves spontaneous and multifaceted, to the momentous events in Russia. In so doing, we will try to contextualize the debate on "1905" in the Greek setting, by discerning the underlying discourses involved, taking into consideration the specificities of the Kingdom of Greece at that historical juncture, its self-image as a state and a society, including its national identity and historical vision.

We will approach our subject matter by using three mainstream Athenian dailies, all three with a wide circulation, the liberal Acropolis, the enlightened conservative Embros and the mildly conservative Scrip.

In the course of 1905, the Greek press devoted almost every day a whole page to the external and internal difficulties faced by tsarist Russia. The pages in question, rarely editorials or large articles, are for the most part short informative texts, in what was apparently a conscious attempt at presenting events as dispassionately and factually as possible. These mostly laconic texts, all placed within one page like pieces of a puzzle, attempted to provide a comprehensive presentation of what was 
taking place in Russia. Their sources of information were for the most part European press agencies and, to a lesser extent, the Athenian Press Agency's office in St. Petersburg. There are also many translations of articles from a number of European dailies, notably The Daily Telegraph and The Times of London, Le Matin of Paris, the Russian Novoe Vremia as well as from the German and Austrian press.

This way of producing and disseminating information gave the news in question a pan-European dimension. This element, together with the extrovert Westernorientated character of the Greek press, placed Greek public opinion within the wider pan-European public debates that had come to the fore in the course of the nineteenth century with the explosion of journalism. From this angle of vision, the study of the press opens up a new perspective, namely a comparative approach of European perceptions of the Russian Revolution of 1905, where one can detect common themes of interest and common attitudes as well as recurring divergences.

As it is generally accepted today, press reports and articles, however avowedly factual, do not simply transmit a news item, but are also in the business of "constructing" the news in question, be it simply by the choice of style and expression or the selection of events being highlighted. ${ }^{1}$ In spite of the short content of most of the press texts published in Athens, the words that were used, together with the titles chosen to top the text, and not least the culture of the image and the photograph, conveyed a particular message to the information in question. In the course of 1905, one sees in the Greek press, for all its attempts at impersonal dispassionate presentation, a dramatic narrative, full of suspense as to how the whole story will end after all, replete with harrowing descriptions of wretchedness, repression and blood-letting, and presenting a sort of ghastly "numbers-lust" as to the exact number of killed persons at each clash. The newspapers seem to rival each other in their attempt at conveying the drama as vividly as possible. This is often done, not surprisingly, at the expense of objective reporting. ${ }^{2}$

In the Russian turmoil as it unfolded throughout 1905, events, as it is well known, changed dramatically, almost on a daily basis. The historical actors were many, each one following his own agenda: workers, farmers, students, soldiers, intellectuals, monarchists, liberals, radical and socialist political parties, national minorities, the government, the tsar... ${ }^{3}$ In the Greek press one can detect, on several occasions, vagueness and puzzlement as regards the main actors involved: who the main actors really were, what their true objectives were, what the wider and longterm consequences of their actions were. And at times, the Greek press, immersed as it was in details of the events, does not seem to understand what was really at stake in Russia in 1905.

1. See Peter Dahlgren-Colin Sparks, eds., Journalism and Popular Culture, London: Sage, 1992.

2. "Ta neotera tou europaikou tahydromiou" [The news of the European postoffice], Scrip, 21 January 1905 , p. 4.

3. Abraham Ascher, The Revolution of 1905: Russia in Disarray, Stanford: Stanford University Press, 1988; Id., The Revolution of 1905. Authority Restored, Stanford: Stanford University Press, 1992; Politicheskie partii Rossii. Konets XIX-pervaia tret' XX V. Entsiklopediia Moscow, 1996. S.V. Tiutiukin, Desiat’ let v zhurnale otechestvennaia istoriia, Moscow: Sobranie, 2005. 


\section{Revolution or reform?}

At the time of the Russo-Japanese War, Greece followed a policy of "benevolent neutrality," according to the assessment of Iu. Ia. Solov'ev, the then secretary of the Russian legation in Athens. But when it came to providing practical assistance to Russia, Greece put neutrality aside, according to Solov'ev, as evidenced by the fact that the Russian warships anchored indefinitely in the port of Piraeus during the war. This was made easier by the lack of diplomatic relations between Greece and Japan at the time. ${ }^{4}$ During the same months, Greek entrepreneurs accumulated considerable profit as suppliers of the Russian navy in the far eastern theatre of war. These suppliers, together with the members of the Greek community in Russia, were to provide the main eyewitness accounts of events in Russia.

As regards the Greek reigning dynasty, the news about the events of 9 January were very painful, particularly insofar as the Greek queen was concerned. Queen Olga Konstantinovna, the wife of reigning King George I of Greece, was the daughter of Grand Duke Konstantin Nikolaevich, Alexander II's elder brother. According to her son, Prince Nicholas, Olga was a fanatical monarchist. ${ }^{5}$ She had very little sympathy for "the new democratic institutions" and was shocked at the very idea of granting a Constitution in her native country. As pointedly put by Iu.Ia Solov'ev in his Memoirs, "I remember her utter astonishment when I told her that a Constitution was absolutely necessary [...] and I got the distinct impression that she regarded me as something of a revolutionary." 6

In contrast, Greek society was positively inclined towards the Russian expressions of popular will, as shown by its enthusiastic support of the peaceful demonstration under priest Gapon and the demands of the demonstrators for civil liberties, a Constitution and labour legislation. As for the high-handed and violent reaction of the Russian authorities, it was condemned without much ado.

In January, the Greek press followed closely the heated discussions in the French Assembly on foreign policy and the Franco-Russian alliance. ${ }^{7}$ The Greek press abounded in reports about the impact of the Russian events in other countries and especially on the staging of antitsarist demonstrations in Paris, Prague, Cracow, Trieste and elsewhere. ${ }^{8}$ In Athens, a small group close to the prosocialist newspaper Metarythmisis [Reform] called the people to similar demonstrations. ${ }^{9}$ However, the authoritative Acropolis and its owner, the liberal Vlassis Gavrilides, the father of

4. Iu.Ia. Solov'ev, Vospominaniia diplomata, 1893-1922, Moscow: Izdatel'stvo sotsial'noekonomicheskoi literatury, 1959, pp. 137-138.

5. Prince Nicholas, Ta peninda chronia tis zois mou [The fifty years of my life], GrekaK.G. Kotzias, Athens, 1926, p. 57.

6. Iu.Ia. Solov'ev, op. cit., p. 142.

7. See in lieu of example the discussions in the French Assembly, including the speech by Delcassé, in Scrip, 19 January 1905, p. 1.

8. On the impact of the Russian Revolution in Paris and the anti-tsarist demonstration there, see details in Scrip, 17 January 1905, p. 5.

9. See Scrip, 31 January 1905, p. 4. 
Greek journalism, cautioned the excited Greek public not to follow the example of the mass public demonstrations in the rest of Europe in support of the victims of Bloody Sunday. His main thrust was the following: "One of our main liberators, one of our main great friends, has been none other than Russia. And it was not the Russia of the nihilists..., nor the Russia of the labour demonstrations, but the official Russia, the Russia of Tsars Alexander I, Nicholas I, Alexander II and Nicholas II. Russia is one of the great powers of today, one of the great powers of tomorrow... [hence] we cannot permit ourselves to react with hostility in the present difficult circumstances in which our coreligionist and great benefactor finds herself, taking for granted the tsar's proclivity to liberalism." 10

Clearly, the national interest of a small dependent state like Greece called for prudence. The Russian Empire was one of the pillars of the existing Eurocentric system of states and one of the guarantors of Greece's independence. Matters were particularly delicate, for at that historical point (around 1905), Greece was in the throws of its irredentist campaign in Ottoman Macedonia and in so doing aggravated Greece's relations with her old rival Bulgaria (the other main contender in the region). In Greek eyes, Russia was regarded as the main supporter, if not the instigator, of Bulgarian assertiveness in Macedonia. This, together with the traditional Greco-Russian rivalry in the patriarchates of the East (Anthioch, Jerusalem, Alexandria), was not conducive to warm feelings on the part of the Greeks towards Russia at the time. On the other hand, Russia's stance on the Cretan question (with St. Petersburg consistently pro-Greek) was duly appreciated. All in all, Russia's position from Crete to Macedonia on to Asia Minor and to the Near East was of utmost significance for Greece under its grandiose Megali Idea (Greek irredentism, from its more modest rendition of acquiring Crete, all the Aegean islands, Epirus and most of Macedonia, to far more ambitious schemes leading to the gates of Constantinople and to Smyrna and the Asia Minor coastline), and called for delicate diplomatic manoeuvring and balancing acts on the part of Athens. Thus, the guideline to foreign policy behaviour had to be based on political realism and not idealism or bouts of sentimentalism.

In spite of this call for Realpolitik, the main thrust in the moderate Greek press was that the Greeks could not but be supportive of the forces in Russia seeking reform. After all, as Gavrilides put it, "the Greeks cannot but hope that the benefits of political freedom can also be enjoyed by the Great Russian nation."11 As in the rest of Europe, the liberal discourse in Greece (of whatever hue or tendency) compared the Russian Empire to the Ottoman Empire, and had concluded as early as the nineteenth century that the bureaucratic, authoritarian regime of the tsars was completely out of tune with "the civilised European nations." Reforms were thus seen as necessary if Russia was to abandon her "awful despotism" and her image as

10. See [Gavrilides], Acropolis, 20 January 1905, p. 1.

11. Ibid. 
"a prison for its peoples" and thus gain her rightful place within Europe as a progressive and liberal civil state. ${ }^{12}$

Within this framework, one of the main questions posed in the Greek press was: how could reforms come about more smoothly and effectively? Should they come about from above or should they spring from below? And will the former suffice and if not, what were the dangers of reforms from below, which would undoubtedly be far more sweeping and probably violently imposed? And what of the entry of the masses into politics and how could one realize this otherwise legitimate goal in an orderly fashion? The Russian predicament gave ample ground for discussions relevant to Greece herself, at a time when there was considerable soul-searching in the wake of the humiliating defeat of the country in the Greek-Ottoman war of 1897.

At this point, it is worth noting that the constitutional monarchy of Greece was one of a handful to have been established worldwide until then (in the Greek case following the brief 1864 uprising). From then on and in spite of the occasional intrusion of the monarch in politics, Greece did not lapse into dictatorial or autocratic rule until well into the 1920s (and mainly in the second part of the 1930s). Furthermore, the civil and political liberties were well established and so was universal (male) suffrage (note that the latter was not the case in many a European country in the 1860s). As for the Greek monarchy, it had often been criticized, and rightly so, for its arbitrary, at times authoritarian, behaviour, but it remained, until the beginning of World War I, a stable basis of authority, and the king symbolized the unity of the nation..$^{13}$

However, following the aforementioned 1897 humiliation, a drastic change in the rules of the game was seen as inevitable and necessary. Revolutionary change by the use of violence en masse was considered a possibility but it gained few adherents. The esteemed politician Stephanos Dragoumis regarded the political situation as unruly and conducive to events such as those taking place in Russia (in 1905). According to Dragoumis, in Russia "the people revolted in order to gain freedoms. Here, they may resort to the same means in order to regain freedoms that are being trodden upon" and he expressed the hope that things would change to the better as soon as possible, so as to avoid a wholesale overturn that could be disastrous to the country. ${ }^{14}$

Early reforms and peaceful evolutionary change were basic values for Greece's political culture in the first years of the twentieth century. They were the mark of progress and development. ${ }^{15}$ According to the prevailing view at the time, changes

12. Ibid. Also by the same author, I Ellas kai o Panslavismos [Greece and Pan-Slavism], Athens, 1869; Embros, 12 January 1905, p. 1; "I apolytarchia" [Absolutism], Scrip, 14 January 1905, p. 1; "I Rossia kai i Tourkia” [Russia and Turkey], Scrip, 20 January 1905, p. 1.

13. G.B. Dertilis, Istoria tou ellinikou kratous, 1830-1920 [History of the Greek state, 18301920], Athens: Hestia, 2005, vol. 1,2.

14. "O kyrios Dragoumis provlepon epanastasin" [Mr Dragoumis forecasts revolution], Acropolis, 2 November 1905, p. 1.

15. G.B. Dertilis, op. cit., vol. 2, pp. 763-766. 
had to be initiated or readily accepted by governments. Otherwise, people would take up arms, and if they did so and "demolished Bastilles", then the outcome could be frightening. 16

Even though popular demands and mobilizations may be justified in a particular time and place, reform by the state itself (the party nominally responsible for reform) should always be the best option so as to prevent these demands from becoming uncontrollable and causing violence and political upheaval. Under the reigning spirit at the time in Greece (contrary to what was to take place from the 1920s onward), the triptych "monarchy-liberalism-reform," even radical reform as in the enlightened example of Alexander II, was not seen as controversial and contradictory for a monarchy. ${ }^{17}$ In the Russian case, the road to liberalism was seen as beneficial not only to the Russian people but also to the monarchy itself, as in the case of Germany some years back. ${ }^{18}$

Within such a context, revolution was often used in the same sense as reform, whereby the masses participated peacefully in a reform instigated from above. The role of the leader-monarch - in this case, that of Nicholas II - was regarded as crucial. The tsar had to adopt reform swiftly and implement it gradually. He had to seize the opportunity and adopt the liberal line, thereby curbing the excesses of the revolutionary movement while at the same time modernizing the country. This middle road, which was adopted at the time in Britain by the defender of an AngloRussian rapprochement W.T. Stead, was the lead followed by most Greek press articles. ${ }^{19}$ The institutional role of the monarch was not put in doubt, and the real and symbolic role of the monarchy in the person of Nicholas II was left untarnished, though he was depicted as inexperienced, weak, perhaps naive. In the first instance he was seen as rational, full of good sense, with a genuine sympathy for the struggling people. This image of the fatherly monarch was well established in the Greek public..$^{20}$ According to this line, the reasons for the existing strains between Nicholas II and the people were to be found mainly in the corrupt imperial court and the backward Holy Synod and above all in the non-credibility and inertia of the bureaucracy, which was hardly inspired by a sense of social duty but acted in a self-serving manner, while the government for its part was not in the position to control it.

As the events unfolded, the tsar was increasingly criticized for his lack of resolve and open-mindedness, his inability to implement the promised reforms, and for having become in effect "hostage" to the imperial court and the bureaucracy.

16. "I epanastasis en Rosia" [The Revolution in Russia], Embros, 18 October 1905, p. 1.

17. [Gavrilides], Acropolis, 20 January 1905, p.1.; "I Rossia kai i Tourkia" [Russia and Turkey], Scrip, 20 January 1905, p.1; Ch. Andriotis (a Greek from Odessa), "I katastasis eis tin Rosian. Oi apolytarchikoi kai oi phileleftheroi" [The situation in Russia: The absolutists and the liberals], Acropolis, 12 December 1905, p. 2.

18. Scrip, 20 January 1905, p. 1.

19. See articles by Stead translated into Greek, in Acropolis, 3 and 4 November 1905.

20. [Gavrilides], Acropolis, 20 January 1905, p. 1. See also Embros, 13 January 1905, p. 4; "Eksoteriki epitherorisis" [International review] Scrip, 16 January 1905, pp. 1-2. 
Nicholas' image was gradually tarnished. He was regarded as lacking not only in courage, but also in perceptiveness, as was the case with Louis XVI on the eve of the French Revolution, whose predicament should be a lesson to all absolute monarchs. Thus, by the last months of 1905, the Greek press began to regard the tsar himself as one of the causes of the revolutionary unrest.

Following the pogrom against the Jews, two more inhibiting factors were added to the ability of the tsar to make bold and far-reaching decisions. These were, according to the Greek press, the ultraconservative circles within the tsar's own ranks on the one hand, and the sinister right-wing opposition to the tsar on the other. The activity of the counter-revolutionary "Black Hundreds," responsible for the pogrom, was deemed criminal and a calculated provocation aiming at forcing the tsar to resort to extreme measures.

In spite of the negative aspects of the Revolution, such as the many wanton acts of violence, the Greek press anticipated that "the river would not go back onto its course," and what would eventually come about at the end would be a new, different, and transformed Russia which made an important step forward towards greater freedom and progress.

\section{Socialism, the internal enemy}

The political dimension of the crisis and the political system were the main areas of concern in Greece. The national question, as one of the reasons for the uprising in Russia, did not go unnoticed, particularly the revolutionary nationalist movements in Poland and Finland. However, the prospect of secession was considered destabilising for the international environment and not supported by the Greeks. Apparently, at this historical juncture, the Greeks, a product of secession themselves from another empire, chose not to identify with other "chained nations" seeking liberation.

Apart from the political dimension, the social question and particularly the labour issue also attracted attention. The workers' demands were meticulously presented in the Greek press (references to the corresponding demands of the peasants are far more sparse), and were considered justified; the need for labour legislation was seen as important, at the very least as a palliative measure aimed at preventing social unrest in Russia. It is within this context that the repressive measures were evaluated, such as the ban on strikes; who was to be responsible for containing strikes (the army or a special police designed to quell internal threats to security); and the level of violence that could be acceptable under dire circumstances (here the question of the proportionality of the violent reaction by the state arose). ${ }^{21}$

By October 1905, the daily reports on events, the details on the clashes, the constant descriptions of bloodbaths, atrocities perpetrated by the revolutionaries and the repressive violence of the "state of the Cossacks," created a constant 
narrative of a revolution that had lapsed into chaos and anarchy, as a bloodstained strife now threatening to engulf the rest of Europe. By November and December 1905 , the descriptions in the press became gloomier and apocalyptic, as the new wave of mobilizations increasingly brought in the more radical and leftist groups and parties such as the Mensheviks, the Bolsheviks and the S.R. By now, the Greek press equated the Revolution with "darkness."

Following the tsarist manifesto of October 1905, the disturbances were regarded as without purpose, leading inevitably to a deadlock, to an insidious "war of all against all." Reports and interpretations of events became ambiguous and contradictory: did the tsar really grant a Constitution, was the Constitution in question worth anything, would it be implemented, would universal suffrage be applied and, above all, were the people indeed able to overthrow absolutism or did they gain very little in return? However, the overall feeling in Greece at the time was that the tsar had given in considerably to the demands of the popular movement.

According to the Greek press, those responsible for the continuing chaos were the Russian "extreme" liberals who got carried away making "extremely democratic demands, the likes of which were badly received, even by truly free and civilized nations [meaning the French and the British]." 22 By doing so, they were responsible, together with the socialists, for the continuing anarchy and violence among the popular strata. ${ }^{23}$ One of the common adages of the Greek press was that the Russian people could not be compared with the other European peoples, including the Greeks, for it was immature and did not have the faintest idea of what freedom really stood for and what was the meaning of a responsible use of freedom for the good of the nation and state. ${ }^{24}$ For instance, the call for universal (male) suffrage by the "extreme liberals" was regarded as exaggerated-a view incidentally voiced by the London Times on the same grounds - for it would have amounted to its being applied to some 80 million people, nine tenths of which were peasants, almost all of them illiterate. ${ }^{25}$

The Greek mainstream journalistic discourse was of the opinion that the continuation of the mobilisations, and in particular the uprising in Moscow, relegated the Russian people to the level of a mob misguided by the nihilists, the anarchists, and the socialists, who were seen as the other end of the terrorist spectrum to the ultra-right-wing "Black Hundreds." Interestingly, the socialists were not seen as genuine reformers, but as selfish destroyers of everything they could lay their hands on. Under their guidance, the strikes and other activities of the revolutionaries lost their value as just and justified demands and became mere agitations. This could only lead to anarchy, where the very essence of fundamental freedoms would be in jeopardy, and several concrete rights would suffer, such as the right to property or the right to free trade. The labour and socialist movements

22. Acropolis, 14 December 1905, p. 3.

23. Ibid.

24. Embros, 30 October 1905, p. 4.

25. Embros, 3 November 1905, p. 4. 
were further denigrated in an array of reports about murders, atrocities and even sacrileges allegedly committed by their members. ${ }^{26}$

The dominant view in Greece was that the labour movement was the ultimate internal enemy of Russia, and European societies as well, particularly when it joined hands with socialism. ${ }^{27}$ In the conservative and liberal Greek milieu of the early twentieth century, socialism was seen as social evil, a threat to the achievements of civilised European nations.

This labelling of socialism as an evil is hardly surprising, for in those days there existed no socialist party in Greece. It was to be created more than a decade later, in the aftermath of World War I, in 1918. This fear of socialism was "imported" from without, from Europe of course. ${ }^{28}$ Furthermore, in the beginning of the twentieth century, Greek society was equipped with weak civil structures and a relatively small proletariat, whose movement was still at an embryonic stage, and there was no mass agrarian movement either. Indeed, the Greeks prided themselves on being a society with limited class differences, by and large egalitarian, by comparison to the rest of Europe. This theoretical lack of class antagonisms had become an ideal that had to be maintained at all cost. According to the prevailing Greek narrative, it was precisely this virtue of Hellenism, this recipe for social harmony which differentiated Greek society from the far more turbulent and unruly European experience..$^{29}$ The Greeks were very sensitive on this issue, for it was precisely then, in the middle of the first decade of the twentieth century, that Greek society became cognizant of the emergence of the wider social question and of the inclusion of hired labour in the fabric of society. It was then that professional unions and workers' organizations made their first appearance and very soon gained the status of autonomous actors, a development that made the established authorities noticeably wary. Thus, the public discussion about what was going on in Russia, with the strikes, the barricades, the strong presence of the socialists and workers, gave ample ground for discussing the Greek experience and the obvious new challenge facing the country: the social question, which had been dormant until then.

As we have seen, in Greece, the 1905 Revolution was an example of a process of change worth avoiding, not least because mass participation on the part of the people was bound to get out of hand, leading to chaos and disaster. However, only two years later, this paradigm regarding "1905" was to come under attack, as a rival new paradigm began to appear, which for the first time placed the pervasive "national

26. Embros, 3 November 1905, p. 4; Acropolis, 4 December 1905, p. 3; "I epanastasis en Rosia" [The Revolution in Russia], Embros, 18 October 1905, p. 1; The daily Scrip, from January onwards, puts great emphasis on the rise of socialism and the dangers of socialist propaganda. See e.g. Scrip, 16 January 1905, p. 4.

27. Scrip, 21 January 1905, p. 3.

28. Antonis Liakos, "I proslipsi tou marxismou stin Ellada" [The perception of Marxism in Greece] in G.B. Dertilis \& K. Kostis, eds., Themata Neoellenikis istorias (18os-19os aionas) [Issues in contemporary Greek history, 18th-19th centuries], Athens: Sakkoulas, 1991, pp. 405-416.

29. Christos Hatziosif (ed.), Istoria tis Ellados tou 20ou aiona, 1900-1922 [History of Greece in the 20th century, 1900-1922], Athens: Vivliorama, 2000, vol. 1, pp. 9-40. 
question" (Greek irredentism, the backbone and raison d'être of the little kingdom since the 1850s) in the context of and interaction with, the social question. This new twist provided the impetus for treating the 1905 Russian Revolution in a different light. The main triggering event for this reappraisal was the publication of a seminal booklet entitled To koinoniko mas zitima [Our social question] by Yiorgos Skliros. Skliros, a Greek of the Diaspora who had studied in St. Petersburg and Germany, put to task the conventional wisdom on the "classlessness" of Greek society, questioning both its actual existence and the view that it was an ideal situation. Skliros, who was apparently influenced by the views of Plekhanov, treated class struggle, in Greece and elsewhere, as a necessary ingredient of progress. In his treatise, Skliros places the 1905 Russian Revolution within the context of a series of European bourgeois revolutions, starting with the French Revolution of 1789, the French revolutions of 1830 and 1848, the German revolutions of 1848 and so on. The Russian 1905 Revolution is placed within the progressive evolution of humanity from one historical stage to the next, from feudalism to capitalism, on to socialism. ${ }^{30}$

\section{"The land of the riddles"}

The Greek reports and comments on the 1905 Revolution have another aspect to them worth highlighting, namely negative and orientalist overtones. The majority of the Greek public at the time was of the view that revolution and socialism were social evils, wherever they came together. However, for the Greeks, as for most Europeans, whenever such events took place in Russia, they were likely to get considerably out of hand. The reason for this malaise was that they simply took place in what was not a fully civilised country. ${ }^{31}$ Particularly in the months of November and December 1905, the Revolution was likened to a monster eating its own flesh. Accordingly, the Russian revolutionaries could hardly be compared with the French revolutionaries of 1789, not least because the Russians clamouring and struggling were not the true offspring of liberty and equality. ${ }^{32}$

According to many a press report, the backward, naive, zealot Russian people thirsted for blood, as was the case with "medieval fanaticism." For instance, one of the writers in Acropolis goes on to argue that the understanding of these events is

30. G. Skliros, Erga [Works], L. Axelos, ed., Athens, pp. 106-108. Rena Stauridi-Patrikiou, O G.Skliros stin Aigypto. Sosialismos, dimotikismos, kai metarythmisi [G.Skliros in Egypt: Socialism, demoticism and reform], Athens: Themelio, 1988.

31. For the European perception of Russia, see Bruno Naarden, Socialist Europe and Revolutionary Russia. Perception and Prejudice, 1848-1923, Cambridge: Cambridge University Press, 1992, especially chapter 4 ; Iver Neumann, Uses of the Other. "The East" in European Identity Formation, Minneapolis: University of Minnesota Press, 1999.

32. See e.g. "I Rosia nikosa tin Rosia. Epanastasis i anarchia, pio to telos?" [Russia overcoming Russia. Revolution or anarchy, what will the end be?], Acropolis, 4 December 1905, p. 3; "Psychikai meletai is tin simerinin Rosian" [Psychic studies in today's Russia], Acropolis, 21 and 22 November 1905 , p. 3 . The comparison of the Russian Revolution with the French Revolution is a constant theme in the Greek press, which needs extensive study in its own right. 
neither the work of the sociologist, nor of the historian, but of the medical doctor, this in view of the fact that "the brain of the Russian people" can absorb information only if it can be transformed into inviolable and sacrosanct religious truths; hence the Russians were deep down incapable of enjoying the fruits of liberty. ${ }^{33}$

These interpretations, often imbued with racism, follow well-established Greek and European stereotypes regarding Russia and the Russians. Russia, be it in revolt or not, was seen as unique and not comparable with any other country in the civilised world. Its religious fanaticism pointed to its dubious European credentials. Even the image of priest Gapon, however heroic and positive (not least in making the cross a symbol of the quest for political liberties), is being used to highlight the religious and zealot character of Russian society, the very antithesis of progress.

There were also several descriptions of Russia by European authors of the time, such as the work of the German Hugo Ganz, entitled The Land of the Riddles: Russia of Today, an excellent description of Russia and the Russian people, which was published in successive editions in the daily Embros, starting in January 1905. In this work, Russia's European credentials are seen as ambivalent. The discourse is semi-Orientalist, ${ }^{34}$ based on the well-known dichotomy of the Enlightenment between civilisation and barbarism, European and non-European. Within this bipolarity, Russia is somewhere in between, having a dual character, partly European and civilised and partly backward, semibarbarian and Asiatic.

This line of thinking was very much in evidence in Athens in 1905. It followed a long tradition prevalent in Europe since the aftermath of the Napoleonic Wars, which tended to stress the negative and darker sides of Russian life in western European eyes. Apart from the writings of what could be dubbed Russo-phobic literature, such as the well-known book by the Marquis de Custine, Russia in 1939, and the notorious "Testament of Peter the Great" (a proven forgery), paradoxically even the works of Russian authors greatly admired in the rest of Europe and Greece were often cited as evidence of Russia's backwardness, semi-European character and uniqueness, instead of being read simply as works of genius and sophistication and as an unmistakable evidence of Russia's place in Europe and world civilisation. The works of Pushkin, Tolstoy, Dostoevsky, and contemporary writers such as Gorky and Kuprin came to be cited as authoritative evidence of Russia's negative traits: one needed only to refer to the vivid descriptions and scathing criticisms of domination, suffering, poverty, hunger, illiteracy, and corruption found in these classic works. Thus, for instance, Dostoevsky's poetic and passionate depiction of the noble "Russian soul" was "translated" in foreign environments negatively, as the "simple folk, easily manipulated by shrewd self-serving agitators." 35

However, to be fair, this was not the only portrayal of Russia in 1905, when it came to its writers and other major figures of the arts and letters, be it in Greece or in

33. Acropolis, 21 November 1905, p. 3.

34. On the terms "semi-Orientalist" see Larry Wolff, Inventing Eastern Europe. The Map of Civilization on the Mind of the Enlightenment, Stanford: Stanford University Press, 1994.

35. Embros, 13 January 1905, p. 2. 
the rest of Europe. Maxim Gorky (an active supporter at the time of the 1905 Revolution) and all the major figures of the nineteenth century, including the celebrated composers, presented a flourishing and vibrant Russia, which though distinct, was certainly European. ${ }^{36}$ As Skrip put it, "the great Russian people, heroes in war, powerful in the sciences, in the arts and in life, powerful in their racial blood, strive to make their flowers blossom even more now with the air of freedom." 37

\section{Harking back to basics: The pan-Slavic spectre}

As we have seen, the Greek press and public were favourable to reforms, though wary of the excesses of violence on both sides. The press was silent, at least momentarily, on the almost paranoiac Greek fear of Russian pan-Slavism in the Balkans. But this was to be only a brief interlude. The year 1905 was hardly over when the old reflexes came back to haunt the Greek public, with the spectre of Russian pan-Slavism, in its role as the imagined awesome threat from the north. In Greek eyes, the vehicle for Russia's "pan-Slavic designs" was none other than Bulgaria, Greece's main foe and antagonist at the time in Macedonia and Thrace within the even wider scheme of Greek irredentism.

For the Greek national discourse of the time (as well as before, from the 1880s onwards), the important internal changes of the Russian Empire, be they liberal or not, amounted to very little, at least in the main areas of concern for the Greeks. Russia, be it under the tsar or the liberals, was bound to remain anti-Greek as far as the "Greek rights" in the Balkans and the Near East were concerned. As put by D. Anastasopoulos (a well-known and frequent commentator in the Greek press) in 1906: "Let us not delude ourselves! Tsarism does not easily crumble, contrary to the belief of the patriots shouting in Athens [...] and even if absolutism were to change to a liberal constitutional monarchy, its policy toward the East (Balkans, Ottoman Empire) would remain unchanged. Pan-Slavism is for Russia a force that is deeply engrained in the genuine pure nature of the Russian psyche." 38

Professor Neoklis Kazazis of the University of Athens, a long-standing critic of Russia's nihilism and expansionist foreign policy along pan-Slavist lines, ${ }^{39}$ reached a similar conclusion a year later, combining Russian nihilism, with anarchism and pan-Slavism. According to Kazazis, Russia was immune to the influences of the industrial revolution, of liberalism or of economic and political progress. It can only absorb nihilistic and revolutionary tendencies within its racially determined

36. See e.g. the article on Maxim Gorky adapted from the French daily Le Matin, in Scrip, 27 January 1905, p. 1; Andriotis, op.cit., Acropolis, 12 January 1905, p. 1.

37. Scrip, 18 January 1905, p. 1.

38. D. Anastasopoulos, Panslavistai, oi megaloi ehthrei tou genous [Pan-Slavists, the great enemies of the Greek race], Athens, 1906, p. 20.

39. See Neoklis Kazasis, "O midenismos en Rosia" [Nihilism in Russia], Parnassos, 12 December 1879. 
pan-Slavic ideology. Consequently, the Russians are inherently against the inviolable rights of the Greeks in Macedonia and against the Greek presence and influence in the Christian East. ${ }^{40}$

To conclude, the 1905 Russian Revolution was a central theme in the Greek public discourse at a time when the feeling was spreading in Greece that the end of a historical period was approaching and a new era in the history of Hellenism was about to dawn.

The perceptions of the Russian Revolution of 1905 by the Greek public were, as we have seen, multilayered, fluid, often contradictory, depending on the historical moment and the vicissitudes of Russia. They were also moulded by the various European discourses about the events in Russia and the political and social situation in Greece herself and not least by the Greek national stereotypes regarding Russia and the Russians. Furthermore, the Russian experience triggered discussion on the following dilemma: whether more democratisation was appropriate in Greece or the opposite was more preferable.

As Eric Hobsbawm has pointed out, from 1890 to 1910, no European government seriously contemplated doing away with its Constitution or parliamentary system of government. ${ }^{41}$ Nevertheless, there was a number of open questions that gave rise to many a heated debate. They included the political system, parliamentarism versus antiparliamentarism, the main elements of government, the rights of the individual, electoral rights, the demand for universal suffrage, popular representation, the control of bureaucracy, the proper role of political parties, socialism and communism, the labour question, the legitimisation of the use of force internally, be it by the state (the legitimate use of violence) or by revolutionary or nationalist movements, in the name of democracy or self-determination.

Our essay was confined almost exclusively to the perceptions of the 1905 Revolution during that very year in Greece. Cleary, another issue worth studying is the perceptions and use of "1905" in the public and political discourse within a wider time span and in conjunction with the catalyst date "1917", the "ten days that shook the world."

\section{University of Athens, Historical Archive}

adialla@archive.uoa.gr

40. Neoklis Kazazis, To Makedonikon provlima [The Macedonian problem], Athens 1907, p. 272. On Kazasis see the recent work by G.Kokkinos, $O$ politikos anorthologismos stin Ellada: to ergo kai oi skepsi tou Neokli Kazasi [Political irrationalism in Greece: The work and thought of Neoklis Kazasis], Athens:Trohalias, 1996.

41. Eric Hobsbawm, The Age of Empire 1875-1914, London: Weidenfeld and Nicolson, 1989, ch. 4 . 